\title{
Policy responses to speculative attacks before and after elections Theory and evidence
}

\author{
Working Paper \\ Author(s): \\ Walter, Stefanie \\ Publication date: \\ 2006 \\ Permanent link: \\ https://doi.org/10.3929/ethz-a-005389071 \\ Rights / license: \\ In Copyright - Non-Commercial Use Permitted \\ Originally published in: \\ CIS working paper 19(2006)
}




\section{uni | eth | zürich \\ Center for Comparative and International Studies (CIS) \\ No 19, 2006}

\section{Working Paper}

Published by the Center for Comparative and International Studies (ETH Zurich and University of Zurich)

\section{Policy Responses to Speculative Attacks Before and After Elections: Theory and Evidence}

by Stefanie Walter

ETH Zurich 


\begin{abstract}
$^{1}$
This paper investigates how electoral timing influences policymakers' responses to currency crises. Previous empirical research has shown that elections significantly influence both the probability that a currency crisis emerges and the government's policy responses to such crises. This paper provides a theoretical explanation for these empirical findings and presents a political business cycle model on exchange rate policy, in which incumbents face a tradeoff between their wish to signal competence and the high cost of exchange rate defenses in response to currency crises. The model predicts that competent incumbents are more likely to defend in response to crises occurring before elections, while incompetent policymakers always devalue. Attacks occurring after elections are predicted to result in devaluations for all types of policymakers. Several empirical implications are derived from the model and are tested for a sample of 61 developing and developed countries for the time period 1970-2003. The results support the predictions of the model and show that 1) defense is more likely before and devaluation is more likely after elections, 2) incumbents who defend their exchange rate before elections have a higher probability of being re-elected, and 3) policymakers are more likely to devalue as the intensity of the crisis increases.
\end{abstract}

Stefanie Walter

Center for Comparative and International Studies

ETH Zurich

Weinbergstr. 11

8092 Zurich

Switzerland

walter@ir.gess.ethz.ch

\footnotetext{
${ }^{1}$ Previous versions of this paper have been presented at the International Studies Association Annual Conference in San Diego CA, March 22-25, 2006 and the Midwest Political Science Association Annual National Conference in Chicago IL, April 7-10, 2005. I would like to thank Thomas Bernauer, John Freeman, Patrick Kuhn, Thomas Sattler, Joshua Walton and Tom Willett for valuable comments.
} 


\section{Introduction}

The influence of elections on economic policymaking has been the subject of a considerable body of research. The literature on political business cycles has argued that during the campaign period, incumbent policymakers deviate from welfare-optimizing policies in order to enhance their re-election chances (Willett 1988; Alesina et al. 1997; Drazen 2001). Since incumbents care about re-election, they manipulate economic policy in order to provide the median voter with a short-term boost in output (e.g. Nordhaus 1975) or in order to signal competence (e.g. Rogoff and Sibert 1988; Rogoff 1990). Other models look at partisan differences as a source of political business cycles (Hibbs 1977; Alesina 1987, 1989). While the empirical evidence for systematic political business cycles in aggregate economic activity has been weak, electorally motivated manipulations of various types of economic policy instruments, such as fiscal transfers or money growth (for example Alesina et al. 1992; Clark and Hallerberg 2000) have been shown to be more robust.

One area in which the link between electoral timing and economic policymaking has been shown to be particularly strong is exchange rate policy. Along with changes in GDP growth or the size of fiscal transfers, voters can easily observe changes in the exchange rate. The incentive to manipulate exchange rate policy stems from the different short- and long term effects of exchange rate changes. Since devaluations generally reduce real income in the short run, postponing a (necessary) devaluation of the exchange rate today increases today's consumption at the expense of future consumption. Because elections decrease politicians' time horizons as the election date approaches, it has been argued that this trade-off generates incentives to a political business cycle, with lower than optimal rates of devaluation before elections and higher rates of devaluation in the post-election period. As for the causal mechanism, more traditional political business cycle models point to the wealth effects of increasing today's consumption and the trade-off between short-run and long-run costs (Schamis and Way 2003), while rational business cycle models show that the trade-off between present and future consumption can be used to signal the incumbent's competence (Stein and Streb 2004).

The empirical evidence is consistent with the predictions of both types of political business cycle models. For the period preceding an election, Blomberg, Frieden, and Stein (2001) show that the 
probability of maintaining a fixed exchange rate increases as an election approaches. Using a slightly different approach, Schamis and Way (2003) find that the probability of instigating an exchange-rate based stabilization program countries was highest in pre-election phases. Several studies find that devaluations and depreciations of the exchange rate tend to be delayed until after elections (Stein and Streb 2004; Frieden et al. 2001), especially when they were associated with a transfer in executive power (Klein and Marion 1997).

This research has provided valuable insights but suffers from two shortcomings: First, all empirical studies cited above focus exclusively on Latin America broadly defined. This may lead to a bias in the results as Latin America has experienced particularly drastic changes in exchange rate policy. Second, there is a big difference between exchange rate manipulation in tranquil time vs. manipulation in times of strong speculative pressure. Exchange rate manipulation for political purposes generally is not pareto optimal and therefore leads to welfare costs. While this holds in tranquil times, manipulating the exchange rate in the face of speculative pressure entails even higher costs ${ }^{2}$. Hence the question arises whether the temptation of exchange rate manipulation with the objective of winning re-election is strong enough for policymakers during crises or whether economic concerns override all political considerations when policymakers find themselves confronted with a currency crisis.

Given that research on political business cycles has been extensive, it is surprising that research investigating whether politically motivated manipulations of the economy persist in periods of economic crisis has been extremely sparse. There has been no theoretical work on this question and only one empirical study has been carried out. Investigating policy responses to speculative attacks on the exchange rate in 90 developing countries, Leblang (2003) finds that the probability of an exchange rate defense increases significantly both before and after elections. This is consistent with the political business cycle models predicting lower rates of devaluation in the run-up to an election, but inconsistent with the prediction that the rate of devaluation will rise in the aftermath of an election. The latter finding is also puzzling in light of research on the emergence of speculative attacks. This literature has shown that speculative attacks are more likely to occur immediately after elections have taken place (Leblang 2002; Leblang and

\footnotetext{
${ }^{2}$ The efficiency costs of defending are particularly high when speculation is justified, i.e. based on bad fundamentals.
} 
Bernhard 2000; Block 2003), suggesting that markets perceive the likelihood of a successful bet on an exchange rate devaluation to be greater in post-electoral periods. Leblang's finding also contradicts the descriptive evidence for a sample of 217 episodes of speculative attacks presented in figure 1, which implies that the probability of an exchange rate defense in response to a speculative attack was highest when such an attack occurred shortly before an election and lowest if it was launched in the aftermath of an election.

*** Figure 1 here $* * *$

It is clear from this discussion that the question whether political business cycles persist in periods of currency crisis warrants more theoretical and empirical clarification. In this paper, I address this gap in current research and develop a rational opportunistic political business cycle model, which illustrates how the timing of elections influences policymakers' choices during speculative attacks. In this model, competent policymakers respond to currency crises by defending the exchange rate in order to signal their competence to voters and thus to increase their re-election chances. The model predicts that defenses are more likely before elections, while the probability of a devaluation strongly increases after elections. Moreover, it predicts that policymakers who defend the exchange rate prior to an election are more likely to be re-elected and that the likelihood of a defense decreases with the severity of the crisis. The evidence presented for 61 industrial and developing countries between 1970 and 2003 supports the predictions of the model.

This paper is structured as follows: The next section presents a rational political business cycle model for exchange rate policy during currency crises and deduces several hypotheses from this model. These hypotheses are subsequently tested in section four. Section five concludes.

\section{Elections and Speculative Attacks: A Political Business Cycle Model}

In order to analyze the influence of electoral timing on policymaker's responses to speculative attacks on their exchange rates, I develop a rational opportunistic political business cycle model in which policymakers choose their policy response in light of both political motivations and 
general welfare considerations. This model roughly follows the setup of a political business cycle model developed by Stein and Streb (2004) for electorally motivated exchange rate manipulation in tranquil times. While the traditional rational political business cycle models focus on manipulations of fiscal policy (Rogoff and Sibert 1988; Rogoff 1990), policymakers in this model manipulate exchange rate and/or monetary policy to improve their re-election chances.

I emulate the traditional rational PBC models (Rogoff 1990; Rogoff and Sibert 1988) as well as Stein and Streb (2004), by assuming that policymakers differ in their competence with which they conduct economic policy. Following the notation used in this strand of literature, I assume that policymakers can be either type "competent" $c$ or type "incompetent" $i$. In this context, "competence" denotes a generally more able policymaker, who is in general more efficient in his (economic) policy decisions. For example, they are able to provide the same amount of public goods at a lower cost than incompetent policymakers. Compared with competent policymakers incompetent policymakers always impose higher aggregate welfare costs on citizens. Consequently, voters always prefer having a competent government, because they implement better economic policy. However, voters cannot directly observe a policymaker's type and therefore vote retrospectively, using the incumbent's past policy choices to infer his level of competence.

Both types of policymakers can be affected by periods of heightened market pressure on their exchange rates. Such crises differ from tranquil times in two important ways: First, when a country's exchange rate comes under strong speculative pressure, policymakers no longer have the discretion to implement any policy measure of their liking. In particular, they no longer have the option to "do nothing". They can, however, choose what kind of policy response they prefer: a devaluation $d e v$ or depreciation ${ }^{3}$ of the exchange rate (and hence external adjustment), or a defense def of the exchange rate level by means of reserve sales and tight monetary policy (and hence internal adjustment). Second, the magnitude of the policy response required to stop the speculative attack increases with the severity of the speculative pressure on the currency. Defenses against mild pressure, for example, consist only of moderate sales of foreign reserves, while strong defenses require much more drastic and painful policy measures involving large

\footnotetext{
${ }^{3}$ In the following I will only talk about devaluation. However, the same model can be applied to the depreciation considerations in countries with more flexible exchange rate arrangements.
} 
sales of foreign reserves and a significant rise in interest rates. Similarly, more severe speculative pressure requires larger amounts of devaluation.

To represent this crisis setting, the model assumes that both response options negatively affect citizens' aggregate welfare, causing welfare costs $C^{d e v}$ and $C^{d e f}$ to voters. These costs represent the aggregate welfare effect on the economy. In the case of a devaluation, $C^{d e v}$ includes the loss of credibility, increases in the price of tradable goods, as well as an increasing debt burden for those holding liabilities denominated in foreign currency. Defending causes costs $C^{\text {def }}$ not only because of the foreign currency reserves spent in the attempt to prop up the exchange rate, but also in terms of the opportunity cost of forgoing potential competitiveness gains. In addition, defending the exchange rate may increase the risk of a future crisis involving more severe speculative pressure. More importantly, the tight monetary policy required to defend against severe market pressure dampens investment and consumption and is likely to spark a recession.

Since incompetent policymakers always cause higher welfare costs than competent policymakers, no matter which policy response incompetent policymakers choose, these costs $C_{i}^{d e v}$ and $C_{i}^{d e f}$ are always higher when implemented by an incompetent policymaker than the costs $C_{c}^{d e v}$ and $C_{c}{ }^{d e f}$ arising when a competent policymaker responds to the same amount of speculative pressure. However, the functional form for each type of cost curve is the same for each type of policy response, i.e. $C_{i}^{d e v}=\mathrm{x}+C_{c}^{d e v}$ and $C_{i}^{d e f}=\mathrm{x}+C_{c}^{d e f}$. The model assumes that the intensity of the two available policy responses increases with mounting speculative pressure $p$, making all cost curves upward-sloping. The cost curves have a minimum at market pressure $p^{0}$ where speculative pressure is zero and neither a devaluation nor a defense of the exchange rate are necessary. The welfare cost associated with $p^{0}$ can be thought of the welfare cost associated with maintaining a given exchange rate peg in tranquil times. From a social welfare maximizing perspective, this is the optimal policy response. The welfare costs to society increase with increasing pressure $p$, such that responding to a speculative attack is always worse than any policy action in tranquility $\left(p^{0}\right)$.

As markets exert increasing levels of speculative pressure on the exchange rate, the cost of responding to this pressure increases regardless of the policy response. However, the functional form of the two cost curves $C_{c, i}{ }^{d e v}$ and $C_{c, i}{ }^{d e f}$ are assumed to differ from each other. The welfare 
costs of a defense $C_{c, i}{ }^{d e f}$ initially rise slower than the costs of devaluation $C_{c, i}{ }^{d e v}$. However, with increasing pressure, defending increasingly requires a tightening of monetary policy. Consequently, as pressure increases $C_{c, i}{ }^{d e f}$ picks up and rises much faster than $C_{c, i}{ }^{d e v}$. This implies that a defense will be more costly than a devaluation when speculative pressure is strong.

Figure 2 depicts how the aggregate cost of the two policy options changes with increasing levels of exchange market pressure. The functional form of the defense-cost curve $C_{c, i}{ }^{\text {def }}$ reflects the consideration that mild and temporary bouts of speculative pressure can usually be successfully addressed by selling foreign reserves to support the exchange rate. More severe speculative pressure, on the other hand, can only be countered through a tightening of monetary policy. Since higher interest rates depress consumption and investment and can induce a recession and rising unemployment, the costs of this policy response increase markedly as soon as reserve sales no longer suffice to sustain the exchange rate. This functional form also reflects the assumption that governments are forced to devalue when the intensity of a speculative attack is too severe. Raising interest rates in order to defend the exchange rate eventually leads to prohibitively high welfare costs, so that devaluation, while also associated with undesirable consequences, becomes the only viable option for very severe speculative attacks. In comparison the flatter cost curve for devaluation $C_{c, i}{ }^{d e v}$ reflects that the negative short-term effects of devaluations on voters' real income is offset in the long-run by a boost in the economy's international competitiveness and hence aggregate output. Nevertheless the cost of devaluing in response to mild pressure is higher than that of defending because of the credibility loss associated with giving up a pegged exchange rate.

In efficiency terms, the optimal response to a speculative attack depends on which response has the lowest costs in aggregate welfare. In our model, this means that when faced with mild levels of speculative pressure, defending the currency is the optimal response, while it is more efficient to respond to severe market pressure by devaluing. It should be noted, that the precise functional form of the two cost curves for defending and devaluing crucially depends on a country's economic structure. For example, the cost of devaluation tends to be smaller in highly exportoriented countries, while a defense is less costly when policy credibility has been closely tied to the exchange rate policy, for example when the exchange rate is used as a nominal anchor. While this implies that countries differ with regard to the level of exchange market pressure at which the 
optimal response changes from a defense towards a devaluation, the model's basic assumption that $C_{c, i}{ }^{d e v}$ and $C_{c, i}{ }^{d e f}$ intersect at some point holds for a large variety of cases.

Voters know that a speculative attack is occurring, but they do not know how severe exchange market pressure is. They do, however, observe what policies the authorities implement in response to the shock. Policymakers also observe whether or not a speculative attack is taking place, but in contrast to voters, they additionally observe the intensity of the speculative pressure. Since policymakers are advised closely by their central banks, they have much better access to information about speculative pressure than the average citizen. Finally, I assume that both the timing of elections and the onset of an attack are exogenous to my model.

I defined the optimal policy response to a speculative attack as the one that is the least costly in aggregate welfare terms. Benevolent, welfare-maximizing policymakers will always implement that policy response. Now assume that incumbents are opportunistic and care not only about maximizing social welfare but also about re-election. All incumbents derive the same benefit $B_{c, i}$ (where $B_{c}=B_{i}$ ) from re-election. This benefit can take the form of retaining policymaking power or of enjoying what Rogoff (1990: 23) calls the "ego rent" derived from the "great honor of being the chief administrator". In some countries, re-election may also allow the continuation of more traditional types of rents. Since policymakers discount the future, $B_{c, i}$ is highest immediately before an election and lowest immediately after an election.

If $B_{c, i}$ is high, this benefit creates a temptation to deviate from the optimal policy response if such a deviation increases the incumbent's re-election chances. However, as in the traditional rational political business cycle model (Rogoff 1990), there is a limit to how much policymakers are willing to deviate from the optimal policy response for opportunistic purposes because incumbents, as representative agents, also care about the aggregate level of welfare in the economy. In particular, I assume that the aggregate welfare costs $C_{c, i}{ }^{d e v}$ and $C_{c, i}{ }^{d e f}$ translate into individual costs to each policymaker, because they, as members of the society, bear the same cost caused by a bad economic situation as any other citizen.

This incentive to deviate, combined with voter's inability to directly observe competency, leads to a signaling game in which competent policymakers manipulate policy to signal their type to 
voters and therefore increase their re-election chances. The temptation to signal $T_{c, i}$ is the difference between the benefit of re-election $B_{c, i}$ and the cost $C_{c, i}{ }^{d e v}$ or $C_{c, i}{ }^{d e f}$ caused by the chosen policy response.

$T_{c, i}$ is higher for competent policymakers than for incompetent policymakers, since the costs caused by their policy choices are always lower than those caused by incompetent policymakers. Competent policymakers' net benefit of re-election is thus always higher than that of incompetent policymakers, making policy manipulation less costly for competent policymakers.

\section{* Figure 2 here *}

Figure 2 shows the competent and incompetent policymakers' welfare cost curves as well as the benefit from re-election $B_{c, i}$ relative to the cost of responding to a given level of speculative pressure $p$ (the horizontal axis). The solid lines denote the costs of defending $C_{c, i}{ }^{d e f}$, while the dotted lines denote the welfare cost of a devaluation $C_{c, i}{ }^{d e v}$. The costs generated by competent policymakers $\left(C_{c}{ }^{d e f}\right.$ and $\left.C_{c}{ }^{d e v}\right)$ are shown in black, those generated by incompetent authorities $\left(C_{c}^{d e f}\right.$ and $\left.C_{c}{ }^{d e v}\right)$ in grey.

All this is common knowledge to both voters and policymakers. In particular, voters understand that competent policymakers will be able to defend the exchange rate against significantly stronger speculative attacks than incompetent incumbents. However, the incumbent's type is the policymaker's private information. Voters do not know whether the incumbent is competent or incompetent. Before the election, the incumbent chooses a policy response by taking into account that voters know how high the net benefit of a given policy response is for each type of policymaker at a given level of speculative pressure and that voters vote retrospectively.

The intensity of speculative pressure can fall into one of three regions (see Figure 2). Region I represents the case of mild speculative pressure $p_{I}$. Here $C_{c, i}{ }^{d e f}\left(p_{I}\right)$ is smaller than $B_{c, i}$ for both types of policymakers. The net benefit of defending the exchange rate against mild pressure is thus positive for both types of incumbent $\left(T_{c, i}{ }^{d e f}\left(p_{I}\right)>0\right)$. Since voters do not know how intense the pressure on the exchange rate is, but do understand that competent policymakers are more likely to successfully defend the currency overall, defending the exchange rate serves as a signal 
of competence. Since the incentive to signal $T_{c, i}$ is positive for both types of policymakers, in region I a pooling equilibrium emerges in which both types defend the exchange rate. It should be noted that for most pressure levels in region one, defense is also the optimal policy response.

In region II, the intensity of the speculative attack increases to medium-level pressure $p_{I I}$. In this region, the cost of defending the exchange rate exceeds the benefit of re-election for the incompetent policymaker. Facing a negative net benefit for a defense, the incompetent policymaker implements the policy that is less costly $\left(C_{i}^{\text {dev }}\left(p_{I I}\right)<C_{i}^{d e f}\left(p_{I I}\right)\right)$. Even though the costs of defending against medium-level pressure are higher than the cost of a devaluation for the competent policymaker as well $\left(C_{c}^{d e v}\left(p_{I I}\right)>C_{c}{ }^{d e f}\left(p_{I I}\right)\right)$, the competent incumbent's net benefit of defending remains positive $\left(T_{c}^{\text {def }}\left(p_{I I}\right)>0\right)$. Knowing that a defense would be too costly to implement for an incompetent incumbent, the competent one chooses a defense of the exchange rate and thus signals his competency to voters. This leads to a perfect separating equilibrium in which a competent policymaker responds to intermediate levels of exchange market pressure by defending the exchange rate, while incompetent policymakers devalue. Voters observe the policy response implemented and re-elect the incumbent only if the exchange rate has been successfully defended.

Note that in region II, competent policymakers defend the exchange rate even though it would be less costly to devalue. Voters honor this choice of a suboptimal policy because this short-term loss in aggregate welfare is compensated by a long-term gain in welfare achieved by having a competent policymaker. ${ }^{4}$

Finally, in region III the country is facing very severe speculative pressure $p_{I I I}$ In order to fight off an attack of this magnitude, very painful policy measures would be required. These policy measures - such as extremely high interest rates - are associated with very high welfare costs. The net benefit of defending the exchange rate against such strong exchange market pressure is negative for both types of incumbents $\left(T_{c, i}{ }^{d e f}\left(p_{I i l}\right)<0\right)$. Knowing that manipulating the policy response will not be rewarded with any net benefit, both types of policymakers devalue their

\footnotetext{
${ }^{4}$ The rationality of implementing this policy response is enhanced by the time asymmetry with which the effects of the two policy responses materialize: the negative effects of a defense generally appear much later than the negative effects of a devaluation, while the positive effects of a defense can be felt mainly in the short-run as opposed to the positive effects of devaluations, which tend to materialize in the long run.
} 
currency when faced with a speculative attack of this intensity. The welfare costs associated with devaluation are still very high, yet since they are lower than those of a defense they still

constitute the optimal response to pressure of this intensity $\left(C_{c, i}{ }^{d e v}\left(p_{I i I}\right)<C_{c, i}{ }^{d e f}\left(p_{I i I}\right)\right)$. In the resulting pooling equilibrium both types of policymakers respond to the attack with a devaluation, making it impossible for voters to separate between competent and incompetent incumbents. In comparison with the other two regions, the chances of re-election therefore decrease for competent policymakers and increase for incompetent policymakers.

Table 1 summarizes the model's predictions about the rate of devaluation chosen by competent and incompetent policymakers when faced with speculative attacks occurring shortly before an election.

* Table 1 here *

The model has several empirical implications. First, the electoral incentive increases the probability that a competent policymaker will choose to defend his country's exchange rate even if the welfare cost of a defense is higher than that of a devaluation.

H1: Relative to non-electoral periods, policymakers are more likely to defend the exchange rate in response to a speculative attack when an election is pending.

Second, the more severe a speculative attack, the more costly is a defense of the exchange rate. The model predicts that the net benefit of a defense decreases with increasing market pressure and finally turns negative. It follows that

H2: The more severe the intensity of a speculative attack, the more likely is a devaluation of the exchange rate in response to such an attack.

Finally, Table 1 also implies that competent policymakers are more likely to defend their exchange rate than incompetent policymakers. While the level of competence cannot be measured empirically, re-election, which in the model is closely tied to the level of competence, 
can be observed. The model predicts that

H3: Policymakers who defend their currency against a speculative attack are more likely to be re-elected than policymakers who devalue.

Since the discounted benefit of a re-election is lowest in the immediate aftermath of an election, the incentive to manipulate the exchange rate in order to signal competence is the lowest in the post-election period. Moreover, policymakers which are newly elected have the option to blame their predecessors' policy for the speculative attack and therefore do not have to worry about citizens' inference about their competence based on their policy response to an attack occurring shortly after an election. The likelihood that policymakers respond by devaluing can hence be expected to be highest in the period following upon an election.

H4: The likelihood of a devaluation is highest in post-electoral periods.

The four empirical implications derived from the model will be tested in the remainder of this paper.

\section{Empirical Analysis}

The empirical implications of the theoretical model are summarized in the four hypotheses discussed above. In this section, I first present the criteria used for the case selection. I then present the operationalization and the empirical tests for the four hypotheses.

\subsection{Data and Operationalization}

This paper investigates the influence of elections on exchange rate policy decisions. It covers 86 countries in both the industrial world and emerging markets between 1970-2003. Since elections matter only in democratic regimes, political business cycles can only be expected to occur in democracies. My analysis therefore only includes democratic countries, i.e. which exhibit at least a value of 5 on the POLITY IV index (Marshall et al. 2002). In addition, I only include countries, 
which have the option to intervene in the behavior of their exchange rate. This is important since in fully floating regimes, governments have no choice between devaluations and defenses and therefore cannot manipulate the exchange rate. I consequently exclude countries scoring a 13 (free float) on Reinhart and Rogoff's de facto exchange rate regime classification (Reinhart and Rogoff 2004) ${ }^{5}$.

Speculative attacks are operationalized as proposed by Eichengreen, Rose and Wyplosz (1996; 2003). Following this widely used approach, I define speculative attacks as periods of extreme pressure in the foreign exchange market and operationalize exchange market pressure (EMP) as a weighted average of exchange rate changes $\left(E_{i, t}\right)$, interest rate changes $\left(r_{i, t}\right)$ and reserve changes $\left(\mathrm{R}_{\mathrm{i}, \mathrm{t}}\right)$ for country $\mathrm{i}$ at time $\mathrm{t}$ relative to the values of these indicators in a stable reference currency $\mathrm{r}$ such as the US dollar or the Deutsche Mark/Euro ${ }^{6}$. These components are weighted by the country-specific variance of each component. Months in which this index of speculative pressure is at least two standard deviations above a country's mean are considered to be speculative attacks $^{7}$. The rationale behind this index is that governments can respond to currency crises either by devaluing or floating their currency, by tightening monetary policy, or by spending foreign reserves in order to buy domestic currency. The data needed for calculating this index is available on a monthly basis for a large number of countries from the International Financial Statistics provided by the IMF (2004). Using this procedure 291 speculative attacks were identified in 44 countries.

Elections are defined as presidential elections in presidential political systems, and parliamentary elections in parliamentary democracies. The type of political system was identified using the World Bank's Dataset of Political Institutions (Beck et al. 2000). Election dates were collected from various sources, most notably the Election Results Archive (CDP 2004).

Pre- and post-electoral periods are operationalized using dummy variables. The first variable

\footnotetext{
${ }^{5}$ I do include fixed exchange rate regimes, however, since policymakers always have the option of abandoning the exchange rate regime in response to a speculative attack. It should be noted that in reality there are almost no „fully floating" exchange rate regimes. However, it makes sense to exclude regimes in which the authorities only intervene to a minimal degree.

${ }^{6}$ The US dollar ist he reference currency for all countries except fort he European and Eastern European countries, for whom the DM or the $€$ is chosen as reference currency.

${ }^{7}$ Some exchange market crises can stretch over a longer period of time. I therefore do not consider months of exchange market pressure which follow immediately in the six months after the initial month of a speculative attack.
} 
takes the value of 1 if the speculative attack occurred within the six months preceding an election, including the election month. While my model assumes that the timing of elections is exogenous, in many countries with parliamentary systems governments have some choice in setting the election date. In order to circumvent the possible endogeneity problem arising from the fact that the choice of the election date may depend on whether or not a speculative attack is occurring, I check for the robustness of my results by using a second dummy variable of the pre-electoral period which takes the value of 1 if the speculative attack occurred within the three months preceding an election. As this time period is shorter, the potential for endogeneity bias is reduced. The post-electoral period is defined as the six months following upon an election. Using this operationalization and limiting my case selection to democratic countries with some degree of exchange rate intervention in the way described above, 38 speculative attacks occurred in the preelectoral period with a 6 month window, 8 of which happened in the pre-electoral period with the 3 month window. In addition, 37 attacks occurred in the six month post-electoral period ${ }^{8}$. Of these attacks, 14 occurred in the 3 months following directly upon the election.

Hypotheses H1, H2 and H4 make predictions about how elections influence policymakers' decision to defend or devalue when their exchange rate comes under speculative pressure. I use two different operationalizations for policymakers response to exchange market pressure: 1) the monthly rate of depreciation $\Delta \mathrm{E}$ of a country's exchange rate and 2) a dummy variable distinguishing between defenses and devaluations.

The monthly rate of devaluation is a direct measure for developments in a country's exchange rate policy. The data for the monthly rate of depreciation is calculated as the monthly change in the exchange rate relative to last month's exchange rate, taken from the IMF's International Financial Statistics. The drawback of this measure is that seemingly large exchange rate swings may still be well in the limits of a relatively loose peg, while relatively small exchange rate changes can be an indicator that a more rigid exchange rate regime has been given up.

In order to tackle this drawback, a second dependent variable is used measuring whether the

\footnotetext{
${ }^{8}$ The similar distribution of speculative attacks before and after elections is surprising since previous research on the occurrence of speculative attacks (for example Leblang and Bernhard 2000; for example Leblang 2002) has indicated that speculative attacks are significantly more likely to occur in post-electoral periods.
} 
exchange rate was defended or devalued in the six months following the speculative attack (or in the months preceding the election for attacks in the pre-electoral period). This dummy variable takes into account that a "devaluation" may mean different things depending on the exchange rate regime. For countries following dollarization, a currency board or monetary union, a devaluation is defined as any deviation from the exchange rate exceeding $1 \%$. For pegged exchange rate regimes a devaluation is defined as a minimum $2.5 \%$ change in monthly exchange rate. Finally, for all other exchange rate regimes this threshold is set to $5 \%$ for OECD and $10 \%$ for all other countries. When determining whether the exchange rate was defended this variable takes into account the month in which the speculative attack occurred as well as the five subsequent months (or, in the case of pre-electoral periods, the months preceding the election, including the election month). If the respective devaluation criterion was met in at least one of these months the policy response is coded as zero, or devaluation. Otherwise, it is coded as defense, and the dummy variable takes the value of one.

\subsection{Electoral Timing and Policy Responses to Speculative Pressure}

How does the timing of elections influence policy responses to mounting exchange market pressure on a currency? A first cut at this question indicates that the prediction of the models - a higher likelihood of a defense before elections followed by a higher incidence of devaluations in the post-electoral period - hold empirically. Table 1 presents the results for regressions analyses in which the two election period dummies are included as the only independent variables. The first two columns show the impact of elections on the exchange rate change in the month of the speculative attack. The coefficients of both pre-electoral period dummies are negative and statistically significant at the $5 \%$ level in these OLS regressions with country clusters. Compared to periods in which no elections are pending, the average rate of devaluation in response to a speculative attack is between $4 \%$ and $5 \%$ lower if an attack occurs during the campaign periods. The results of the logit models shown in columns three and four also indicate that the likelihood of a defense increases in the pre-electoral period.

* Table 2 here *

The evidence for the post-electoral period is less clear. Hypothesis $\mathrm{H} 4$ states that in the aftermath 
of an election, policymakers regardless of their type are more likely to respond to a speculative attack by devaluing their exchange rate. The results in table 2 paint a mixed picture: If a speculative attack occurs in the six months following upon an election, the rate of devaluation increases as expected, albeit not at a statistically significant level. However, if the attack occurs within the first three months following upon an election, the rate of devaluation actually decreases. As expected, the results for the defense dummy variable indicate that the probability of a defense decreases after the election. These results suggest that the probability of a successful exchange rate defense is around $60 \%$ in the six months preceding an election, but only $38 \%$ in the six months post-electoral period.

As predicted by the model, elections thus induce policymakers to change their behavior, an indication that political business cycle manipulations of the exchange rate policy persist during times of crises.

Naturally, election periods are not the only issue policymakers consider when deciding about how to respond to a speculative attack. Several other factors restrain and shape the policy options available. The question therefore arises whether the results presented in table 1 hold when these factors are controlled for. Table 2 presents the results for multivariate OLS analyses (columns 1 and 2) and logit analyses (columns 3 and 4), in which these additional factors are controlled for. The eight control variables that have been added to the model are the level of development, the current account deficit, the level of foreign reserves, real exchange rate appreciation, the rate of inflation, a dummy variable for capital controls, and the de jure exchange rate regime.

The first six variables control for economic factors, which have been found to be important in the context of speculative attacks. They are taken from the IMF's International Financial Statistics database (IMF 2004) and are mostly lagged by one month in order to represent the information available to policymakers at the time of the attack. First generation crisis models (Krugman 1979) suggest that bad fundamentals - in particular budget deficits - are a major cause of crisis and will result in a devaluation of the exchange rate. The first control variable is consequently the budget surplus, lagged by one month. As budget deficits are said to increase the probability of a devaluation, this coefficient is expected to be positive. The level of development is measured as GDP per capita and is expected to yield a negative coefficient as richer countries tend to have 
more resources for withstanding speculative attacks, so that the resulting rate of devaluation should be smaller. The current account surplus is measured as (exports-imports)/GDP over the past year and is also expected to enter the equation positively: countries highly dependent on exports are more likely to devalue in order to reap the competitiveness gains associated with lower exchange rates (Walter 2005). The level of foreign reserves, adjusted in relation to base money, is expected to enter the regression equation negatively, since exchange rate defenses are more feasible the higher the central bank's foreign reserves. Real exchange rate overvaluation is expected to increase the rate of devaluation, as it reduces a country's international competitiveness and therefore makes a defense of the devaluation less advantageous. The variable takes positive values for undervalued and negative values for overvalued real exchange rates. The coefficient is therefore expected to enter the equation negatively. Finally, the rate of devaluation should increase when governments face high rates of inflation, as this monetary expansion puts additional pressure on the exchange rate.

Two additional variables - the presence of capital controls and the de jure exchange rate regime are used to account for the institutional context in which the policymakers make their decisions. These data are taken from the dataset provided by Ghosh, Gulde, and Wolf (2003) and are based on the IMF's Annual Report on Exchange Arrangements and Exchange Restrictions. Capital controls obstruct the capital flight usually associated with a currency crisis and thus facilitate a defense. The coefficient for capital controls is therefore expected to enter the equation negatively. Since the exit costs associated with devaluations increase with the rigidity of the proclaimed exchange rate regime, I expect the presence of more rigid de jure exchange rate regimes to increase the probability of a currency defense. The variable takes higher values for more flexible regimes and is therefore expected to enter the regression with a positive sign.

\section{* Table 3 here *}

Table 3 shows the results for the multivariate regressions. Note that the explained variance increases considerably when these additional variables are added. Controlling for these additional variables, the effect of electoral timing on the rate of exchange rate change (columns 1 and 2) observed in table 1 remains essentially unchanged. Compared with non-electoral periods, the rate of exchange rate devaluation is significantly lower (between $2.6 \%$ and $2.8 \%$ ) if the attack occurs 
prior to an election. The evidence concerning the policy response to attacks occuring in the aftermath of an election is more mixed. The coefficients for the economic control variables all point in the expected directions. The rate of inflation as well as a country's export orientation have a very significant ( $1 \%$ level) influence on the response to a speculative attack, while the level of development and the extent of overvaluation also significantly influence the rate of devaluation chosen in response to an attack. The institutional variables, however, produce some puzzling results. Capital controls increase rather than decrease the likelihood of a devaluation, possibly an indication that the threat of capital controls can hasten rather than slow capital flight and consistent with the evidence that the probability of a currency crisis is higher in the presence of capital controls (Willett et al. 2005). Even more surprisingly, more flexible exchange rate regimes lead to significantly lower rates of devaluation than more rigid exchange rate regimes.

Looking at the overall policy response (columns 3 and 4), the political business cycle model predicts the post-electoral policy response better than the pre-electoral response. As predicted, the likelihood of devaluation markedly increases in the aftermath of an election. The coefficient for the 6-month period is significant at the 5\% level and decreases the probability of an exchange rate defense by $22.5 \%{ }^{9}$ (from $57.2 \%$ to $34.7 \%$ ). The coefficient for attacks occurring within the three months after an election is also negative (a decrease in the probability of defense by $14.6 \%$ ), but not significant. Contrary to the model's predictions, if the attack occurs within six months before an election, the probability of an exchange rate defense decreases. If it occurs within three months of an upcoming election, however, the probability of a defense increases slightly by $6.5 \%$ (from $53.1 \%$ to $59.6 \%$ ). However, neither coefficient reaches statistical significance. The impact of the control variables also changes when compared to the analysis of the exchange rate change. As above, and as expected, a budget surplus, a high level of reserves, and a low degree of real exchange rate appreciation increase the probability of a defense, while high inflation significantly lowers the probability of a defense. More flexible de jure exchange rate regimes are more likely to defend their exchange rate. Apparently, this flexibility gives them the opportunity to respond to mounting speculative pressure without a major devaluation. Surprisingly, richer countries and countries with capital controls are more likely to devalue, while countries exhibiting a current account surplus are more likely to defend. The overall model fit is satisfactory: the models predict 62\% (Model 1) and 65\% (Model 2) of the cases correctly, with a

\footnotetext{
${ }^{9}$ Holding all other variables at their median.
} 
reduction in error of $27 \%$ and $21 \%$.

In conclusion, the evidence presented in this section overall lends support to the predictions of the political business cycle model. This support is strongest for the hypotheses stating that in comparison to non-electoral periods the rate of devaluation decreases when elections are pending (hypothesis H1). When policy responses overall are considered, the probability of a devaluation significantly increases in the six months election aftermath (hypothesis H4).

\subsection{Severity of Attack and Policy Response}

Finally, the model makes predictions about the relationship between the severity of a speculative attack and the likelihood of a currency defense. Hypothesis H2 predicts that more severe speculative attacks are more likely to result in a devaluation of the exchange rate, independent of the policymakers' level of competence. In order to test this hypothesis, the policy responses to weak, medium-level and severe speculative attacks are compared (Figure 3). Weak crises are crises for which the value of the EMP-index is at least .3 standard deviations below the median value of the EMP-index for crises, while strong crises are crises in which the EMP-index exceeds this median value by at least .3 standard deviations ${ }^{10}$. Devaluations and defenses are operationalized with the defense dummy.

\section{* Figure 3 here *}

Figure 3 compares the policy responses to speculative attacks of varying severity in pre-electoral periods with those of the remaining time periods. As predicted, in the pre-electoral period defenses constitute a much more frequent policy response to mild and medium-level attacks than during times in which no elections are pending. The fact that approximately one third of mild and medium-level attacks result in devaluations may be because in some economies, devaluations are beneficial even at fairly low levels of speculative pressure (see the discussion above). The picture changes for severe attacks: here the proportion of devaluations increases markedly to one half. This is not wholly consistent with the model, which predicts that a pooling equilibrium will

\footnotetext{
${ }^{10}$ These threshold values were chosen because they result in a fairly equal distribution of crises in mild, medium and severe crises.
} 
emerge in face of very severe attacks, in which all policymakers decide to devalue the currency, but the evidence does point in the expected direction, particularly when the non-electoral periods are considered.

\subsection{Policy Response and Re-Election}

In addition to the hypotheses concerning the expected rate of devaluation, the model also makes predictions about the behavior of competent and incompetent policymakers. While the policymaker's type is unknown not only to the voter but also to the political scientist, what can be observed empirically is whether a policymaker is re-elected or not. Hypothesis H3 predicts that policymakers who defend their currency against speculative attacks are more likely to be reelected than policymakers who devalue. Table 4 shows that policymakers who defended the exchange rate against a speculative attack occurring before the election had a significantly higher probability of being re-elected than those who devalued $(\mathrm{p}=0.033)$.

*** Table 4 here $* * *$

Almost $67 \%$ of all policymakers who defended the exchange rate were re-elected, while for policymakers who chose to devalue in response to a speculative attack this probability dropped to $28.6 \%$. The empirical evidence thus strongly supports the model's prediction that incumbents who defend their exchange rate against a speculative attack have a higher probability of being reelected than incumbents who devalue (hypothesis 3). It also supports the notion that voters observe the policy response in order to gauge the incumbent's level of competency. These findings are consistent with Leblang's (2005) finding that politicians are punished for deviating from a promise that the exchange rate regime will remain fixed and with the evidence that a devaluation increases the likelihood that a political leaders will lose office.

However, a defense does not automatically lead to re-election: six out of the 18 policymakers in the sample who defended lost their bid for re-election despite the defense. A possible explanation for this result is that in real life, exchange rate policy is not the only policy voters evaluate in order to determine a policymaker's level of competence. For example, voters could view the fact, that the national currency is being attacked by speculators in the first place, as an indicator that 
the incumbent is not competent, independent of whether the incumbent defends or devalues the exchange rate.

\section{Conclusion}

This paper has presented a rational business cycle model, which explains how policymakers respond to currency crises. This model argues that prior to elections, policymakers engage in a signaling game with the electorate. When confronted with a speculative attack on their exchange rate, competent policymakers respond differently than incompetent policymakers. While all policymakers defend the exchange rate in response to mild exchange market pressure, a separating equilibrium emerges for intermediate levels of speculative pressure. Here competent policymakers defend the exchange rate against a speculative attack and are subsequently reelected while incompetent policymakers devalue and lose re-election. All policymakers devalue in response to very severe attacks, which leads to a pooling equilibrium in which re-election becomes uncertain for both types of policymakers. Immediately after an election has taken place the probability of a devaluation is highest.

The empirical evidence lends support to the signaling model. Compared to non-electoral and post-electoral periods, the average rate of devaluation is significantly lower if elections are pending. In the aftermath of elections, the probability of a devaluation increases (even though the rate of devaluation in the first month after the attack does not significantly increase). Strong support was found for the hypothesis that policymakers who decide to defend their exchange rate are more likely to be re-elected than policymakers who devalue. Moreover, more severe crises are more likely to result in devaluations than mild crises. The majority of attacks in the preelectoral period nevertheless fails as policymakers choose to defend their exchange rates.

The most puzzling result of this analysis is that the results slightly change depending on the operationalization of the dependent variable as a short-term response (the exchange rate change in the month of attack) and a more general policy response variable (defense vs. devaluation in the six months following upon the attack). Future research should therefore analyze more carefully under which conditions policymakers engage in the signaling game in the short term 
and when they decide to follow this strategy in the longer term. Moreover, more research is needed on the question why the signaling mechanism is successful only in some cases. Detailed case studies investigating the dynamics of currency crises surrounding elections more closely should be able to cast more light on these questions.

The main contribution of this paper has been to show that political institutions such as elections can have an important influence on economic policy-making. While this has been amply demonstrated in the literature on political business cycles, my study shows that electoral considerations remain critical even in times of severe economic stress. This is an important finding: politics and political institutions matter in tranquil and crisis periods alike. 
Figure 1: Policy Responses to Speculative Attacks in Pre-, Post-, and Non-electoral Periods

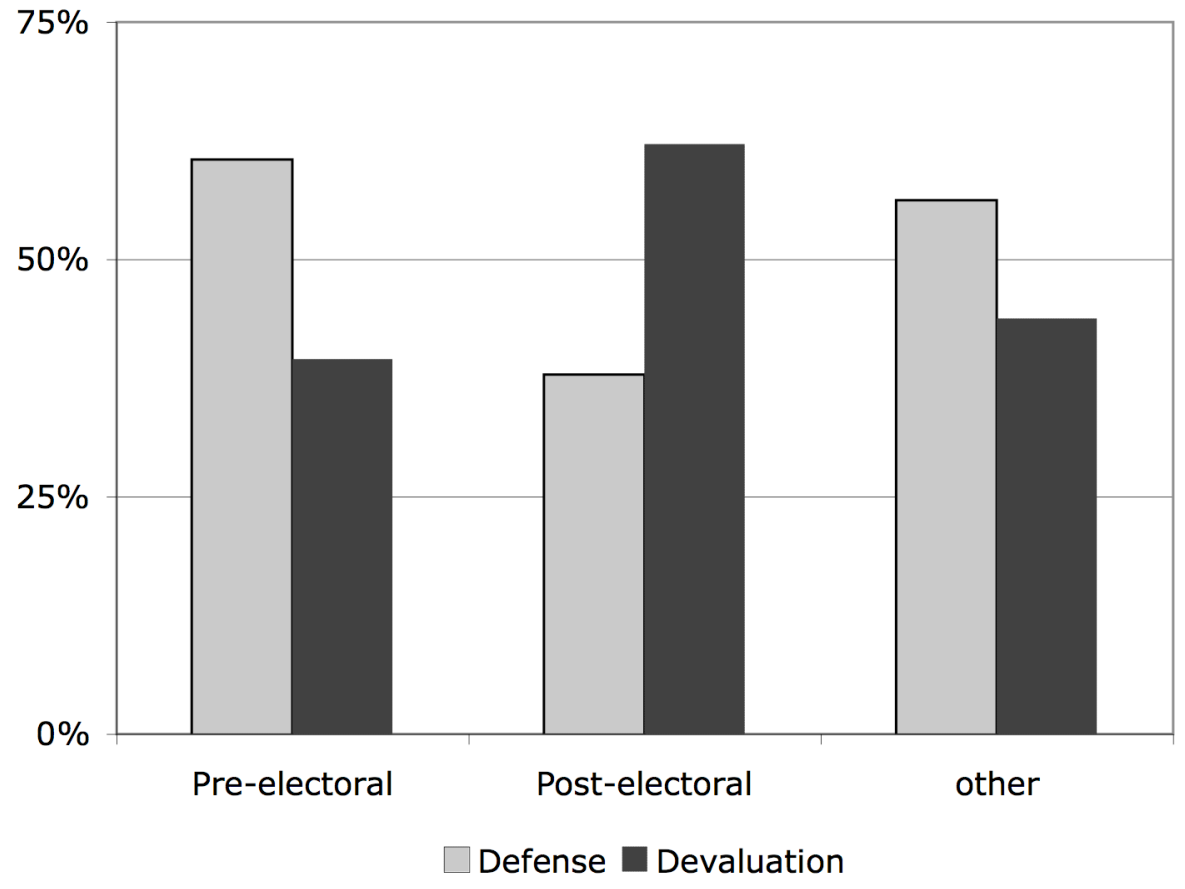


Figure 2: Policy Responses to Speculative Pressure

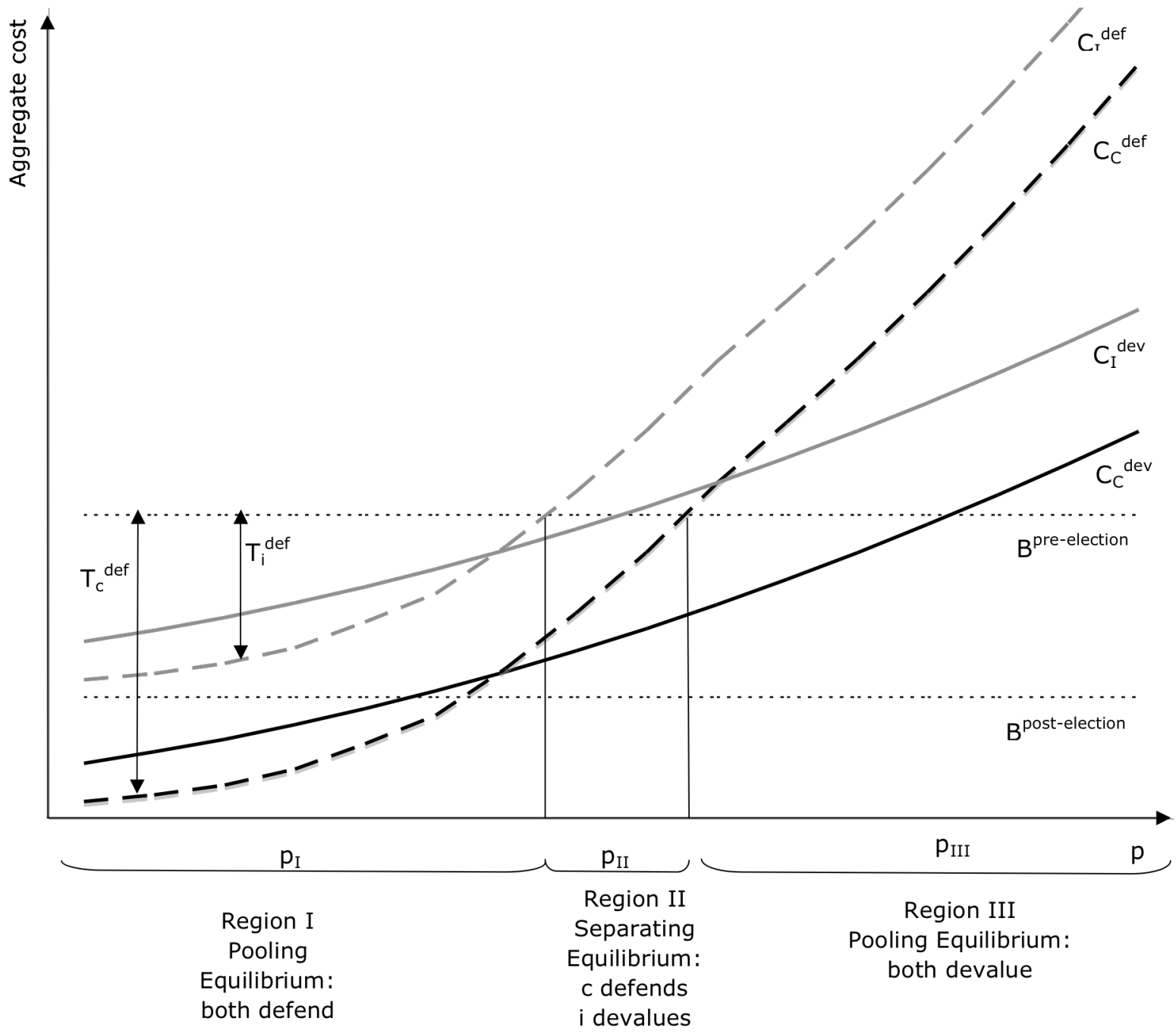


Figure 3: Severity of Attack and Choice of Policy Response

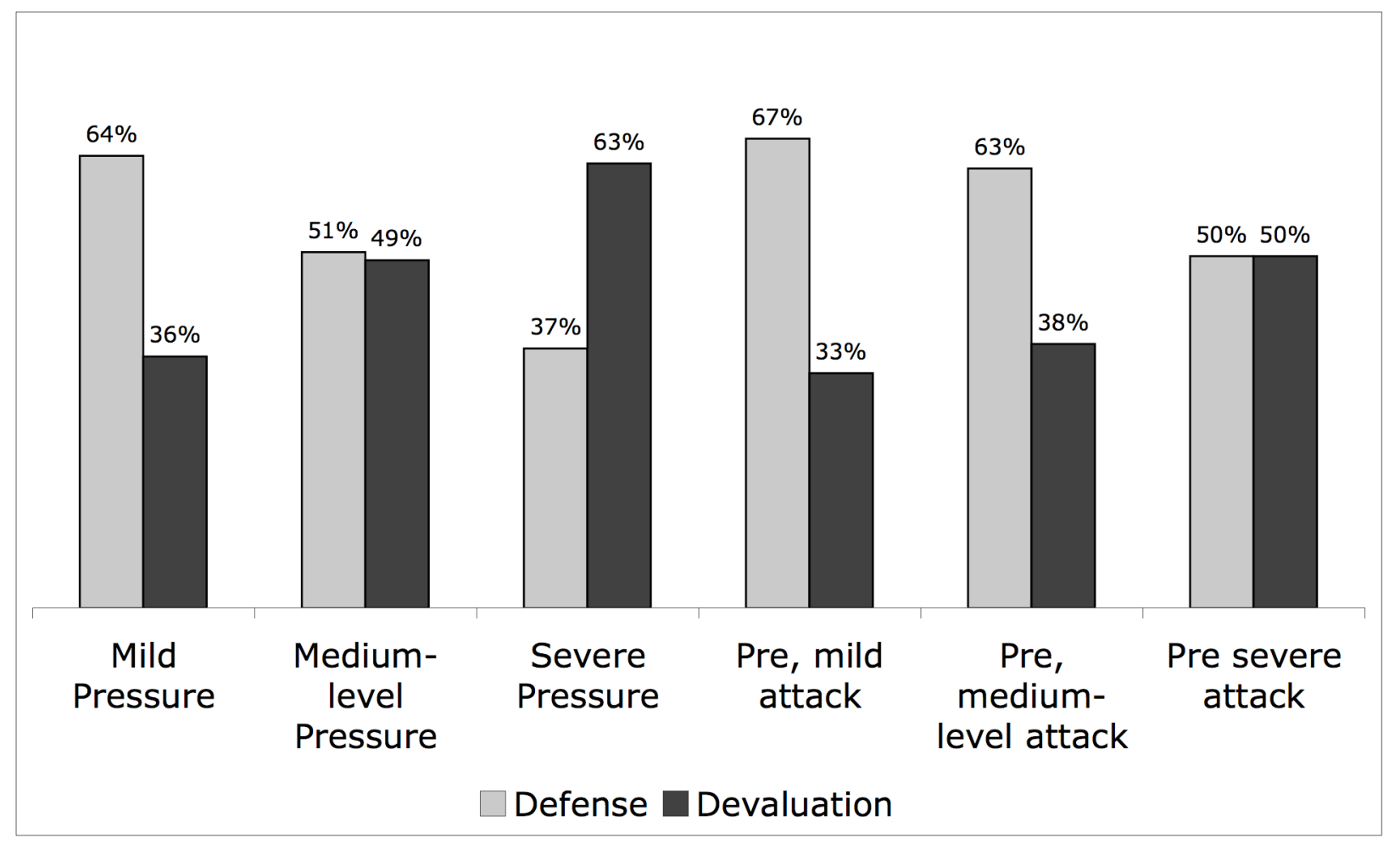


Table 1: Predicted Policy Responses

\begin{tabular}{|l|c|c|c|}
\hline & Mild pressure $p_{I}$ & Intermediate pressure $p_{I I}$ & Severe pressure $p_{I I I}$ \\
\hline $\begin{array}{l}\text { Competent } \\
\text { policymaker }\end{array}$ & Defend & Defend & Devalue \\
\hline $\begin{array}{l}\text { Incompetent } \\
\text { policymaker }\end{array}$ & Defend & Devalue & Devalue \\
\hline & Pooling Equilibrium & Separating Equilibrium & Pooling Equilibrium \\
\hline
\end{tabular}

Table 2: Influence of Elections on the Rate of Devaluation in Currency Crisis Periods

\begin{tabular}{|c|c|c|c|c|}
\hline & $\begin{array}{c}\text { Monthly } \\
\text { change in } \\
\text { exchange rate } \\
\text { in month of } \\
\text { attack } \\
\text { (OLS) }\end{array}$ & $\begin{array}{c}\text { Monthly } \\
\text { change in } \\
\text { exchange rate } \\
\text { in month of } \\
\text { attack } \\
\text { (OLS) }\end{array}$ & $\begin{array}{c}\text { Policy } \\
\text { Response } \\
\text { Dummy (1= } \\
\text { Defense) } \\
\text { (Logit) }\end{array}$ & $\begin{array}{c}\text { Policy } \\
\text { Response } \\
\text { Dummy (1= } \\
\text { Defense) } \\
\text { (Logit) }\end{array}$ \\
\hline Pre-election Period & $-0.049 * *$ & & 0.177 & \\
\hline (6 month window) & $(0.02)$ & & $(0.38)$ & \\
\hline Post-election & 0.020 & & $-0.747 * *$ & \\
\hline $\begin{array}{l}\text { Period } \\
\text { ( } 6 \text { month window) }\end{array}$ & $(0.03)$ & & $(0.31)$ & \\
\hline Pre-election Period & & $-0.043 * *$ & & 0.361 \\
\hline (3 month window) & & $(0.02)$ & & $(0.52)$ \\
\hline Post-election & & $-0.040 *$ & & -0.466 \\
\hline $\begin{array}{l}\text { Period } \\
\text { (3 month window) }\end{array}$ & & $(0.02)$ & & $(0.52)$ \\
\hline Constant & $\begin{array}{c}0.078 * * * \\
(0.02)\end{array}$ & $\begin{array}{c}0.079 * * * \\
(0.02)\end{array}$ & $\begin{array}{l}0.250 \\
(0.17)\end{array}$ & $\begin{array}{l}0.178 \\
(0.15)\end{array}$ \\
\hline $\mathrm{R}^{2}$ & 0.0077 & 0.0038 & 0.0123 & 0.0033 \\
\hline Prob $>$ F/ Chi ${ }^{2}$ & 0.0145 & 0.0948 & 0.0337 & 0.5076 \\
\hline $\mathrm{N}$ & 292 & 292 & 292 & 292 \\
\hline
\end{tabular}


Table 3: Multivariate OLS Regression for Crisis Periods (with country clusters)

\begin{tabular}{|c|c|c|c|c|}
\hline & $\begin{array}{c}\text { Monthly } \\
\text { change in } \\
\text { exchange rate } \\
\text { in month of } \\
\text { attack } \\
\text { (OLS) }\end{array}$ & $\begin{array}{c}\text { Monthly } \\
\text { change in } \\
\text { exchange rate } \\
\text { in month of } \\
\text { attack } \\
\text { (OLS) }\end{array}$ & $\begin{array}{c}\text { Policy } \\
\text { Response } \\
\text { Dummy (1= } \\
\text { Defense) } \\
\text { (Logit) }\end{array}$ & $\begin{array}{c}\text { Policy } \\
\text { Response } \\
\text { Dummy (1= } \\
\text { Defense) } \\
\text { (Logit) }\end{array}$ \\
\hline Pre-election Period & $-0.028 *$ & & -0.279 & \\
\hline (6 month window) & $(0.02)$ & & $(0.46)$ & \\
\hline Post-election Period & 0.025 & & $-0.919 * *$ & \\
\hline (6 month window) & $(0.03)$ & & $(0.36)$ & \\
\hline Pre-election Period & & $-0.026^{*}$ & & 0.267 \\
\hline (3 month window) & & $(0.01)$ & & $(0.63)$ \\
\hline Post-election Period & & -0.030 & & -0.594 \\
\hline (3 month window) & & $(0.02)$ & & $(0.56)$ \\
\hline \multirow[t]{2}{*}{ Budget Surplus (t-1) } & -0.064 & -0.067 & 0742 & 0.966 \\
\hline & $(0.04)$ & $(0.04)$ & $(0.68)$ & $(0.67)$ \\
\hline \multirow[t]{2}{*}{ Log GDP per Capita } & $-0.025 * *$ & $-0.025 * *$ & -0.074 & -0.075 \\
\hline & $(0.01)$ & $(0.01)$ & $(0.12)$ & $(0.12)$ \\
\hline Current Account & $0.269 * * *$ & $0.267 * * *$ & 1.339 & 1.235 \\
\hline Surplus & $(0.08)$ & $(0.08)$ & $(1.80)$ & $(1.90)$ \\
\hline Foreign Currency & -0.036 & -0.035 & $1.296 * *$ & $1.312 * *$ \\
\hline Reserves (t-1) & $(0.02)$ & $(0.02)$ & $(0.54)$ & $(0.53)$ \\
\hline \multirow[t]{2}{*}{ Overvaluation (t-1) } & $-0.000 * *$ & $-0.000 * *$ & $0.000 *$ & 0.000 \\
\hline & $(0.00)$ & $(0.00)$ & $(0.00)$ & $(0.00)$ \\
\hline \multirow[t]{2}{*}{ Log inflation rate } & $0.067 * * *$ & $0.068 * * *$ & $-1.652 * *$ & $-1.555 * *$ \\
\hline & $(0.02)$ & $(0.02)$ & $(0.76)$ & $(0.68)$ \\
\hline \multirow[t]{2}{*}{ Capital Controls } & 0.009 & 0.007 & -0.301 & -0.301 \\
\hline & $(0.02)$ & $(0.02)$ & $(0.47)$ & $(0.47)$ \\
\hline De jure Exchange Rate & $-0.005^{*}$ & $-0.005^{*}$ & 0.034 & 0.033 \\
\hline Regime & $(0.00)$ & $(0.00)$ & $(0.04)$ & $(0.04)$ \\
\hline \multirow[t]{2}{*}{ Constant } & $0.257 * * *$ & $0.263 * * *$ & 0.722 & 0.564 \\
\hline & $(0.09)$ & $(0.08)$ & $(0.92)$ & $(0.93)$ \\
\hline Prob $>$ F $/ \mathrm{Chi}^{2}$ & 0.0000 & 0.0000 & 0.0042 & 0.0058 \\
\hline Adj. $\mathrm{R}^{2} /$ Count $\mathrm{R}^{2}$ & 0.2243 & 0.2200 & 0.648 & 0.617 \\
\hline Adj. Count $\mathrm{R}^{2}$ & & & 0.274 & 0.211 \\
\hline $\mathrm{N}$ & 196 & 196 & 196 & 196 \\
\hline
\end{tabular}

Values in parentheses are standard errors. ${ }^{*} \mathrm{p}<.1 ; * * \mathrm{p}<.05 ; * * * \mathrm{p}<.01$ 
Table 4: $\quad$ Policy Response and Re-election

\begin{tabular}{|c|c|c|}
\hline & Defense & Devaluation \\
\hline Re-elected & 12 & 4 \\
\hline Defeated & 6 & 10 \\
\hline
\end{tabular}

Pearson Chi2 $=4.5714(p=0.033)$ 


\section{References}

Alesina, Alberto. 1987. Macroeconomic Policy in a Two-Party System as a Repeated Game. Quarterly Journal of Economics 102:651-78.

Alesina, Alberto. 1989. Politics and Business Cycles in Industrial democracies. Economic Policy 8:57-98.

Alesina, Alberto, Gerald D. Cohen, and Nouriel Roubini. 1992. Macroeconomic Policy and Elections in OECD Democracies. Economics and Politics 4:1-30.

Alesina, Alberto, Nouriel Roubini, and Gerald D. Cohen. 1997. Political Cycles and the Macroeconomy. Cambridge MA: The MIT Press.

Beck, Thorsten, George Clarke, Alberto Groff, Philip Keefer, and Patrick Walsh. 2000. New tools and new tests in comparative political economy: The Database of Political Institutions. Washington DC: World Bank Working Paper Series, WPS 2283.

Block, Steven A. 2003. Political conditions and currency crises in emerging markets. Emerging Markets Review 4:287-309.

Blomberg, S. Brock, Jeffry A. Frieden, and Ernesto Stein. 2001. Sustaining Fixed Rates: The Political Economy of Currency Pegs in Latin America.

CDP, Center on Democratic Performance. 2004. Election Results Archive Center on Democratic Performance, 2004 [cited 2004]. Available from http://cdp.binghamton.edu/era/countries/index.html.

Clark, William Roberts, and Mark Hallerberg. 2000. Mobile Capital, Domestic Institutions, and Electorally Induced Monetary and Fiscal Policy. American Political Science Review 94 (2):323-46.

Drazen, Allan. 2001. The Political Business Cycle After 25 Years. In NBER Macroeconomics Annual 2000, edited by B. Bernanke and K. Rogoff. Cambridge MA: The MIT Press.

Eichengreen, Barry, Andrew Rose, and Charles Wyplosz. 1996. Contagious Currency Crises: First Tests. Scandinavian Journal of Economics 98 (4):463-84.

Eichengreen, Barry, Andrew Rose, and Charles Wyplosz. 2003. Exchange Market Mayhem: The Antecedents and Aftermath of Speculative Attacks. In Capital Flows and Crises, edited by B. Eichengreen. Cambridge, MA: MIT Press.

Frieden, Jeffry, Piero Ghezzi, and Ernesto Stein. 2001. Politics and Exchange Rates: A CrossCountry Approach. In The Currency Game: Exchange Rate Politics in Latin America, edited by J. Frieden and E. Stein. Washington DC: Inter-American Development Bank.

Ghosh, Atish R., Anne-Marie Gulde, and Holger C. Wolf. 2003. Exchange Rate Regimes. Choices and Consequences. Cambridge: MIT Press.

Hibbs, D. 1977. Political Parties and Macroeconomic Policy. American Political Science Review 71:1467-87.

International Financial Statistics. International Monetary Fund, Washington DC.

Klein, Michael W., and Nancy P. Marion. 1997. Explaining the duration of exchange-rate pegs. Journal of Development Economics 54:387-404.

Krugman, Paul. 1979. A Model of Balance of Payments Crises. Journal of Money, Credit and Banking 11 (3):311-25.

Leblang, David. 2002. The Political Economy of Speculative Attacks in the Developing World. International Studies Quarterly 46 (1):69-92.

Leblang, David. 2003. To Devalue or to Defend? The Political Economy of Exchange Rate Policy. International Studies Quarterly 47 (4):533-559. 
Leblang, David. 2005. Pegs and Politics. Paper read at American Political Science Association Annual Meeting, September 1-4, 2005, at Washington DC.

Leblang, David, and William Bernhard. 2000. The Politics of Speculative Attacks in Industrial Democracies. International Organization 54 (2):291-324.

Marshall, Monty G., Keith Jaggers, and Ted Gurr. 2002. Polity IV Project. Political Regime Characterists and Transitions, 1800-2000. URL: http://www.cidem.umd.edu/inscr/polity/ (consulted December 3, 2003).

Nordhaus, W. 1975. The Political Business Cycle. Review of Economic Studies 42:169-90.

Reinhart, Carmen M., and Kenneth Rogoff. 2004. The Modern History of Exchange Rate Arrangements: A Reinterpretation. The Quarterly Journal of Economics 119 (1):1-48.

Rogoff, Kenneth. 1990. Equilibrium Political Budget Cycles. American Economic Review 80:2136.

Rogoff, Kenneth, and Anne Sibert. 1988. Elections and Macroeconomic Policy Cycles. NBER Working Paper 1838. Cambridge, MA: Nationall Bureau of Economic Research.

Schamis, Hector E., and Christopher R. Way. 2003. The Politics of Exchange Rate-Based Stabilization. World Politics 56:43-78.

Stein, Ernesto, and Jorge M. Streb. 2004. Elections and the timing of devaluations. Journal of International Economics 63 (1):119-45.

Walter, Stefanie. 2005. Speculative Attacks and the Private Sector. Paper read at Midwest Political Science Association Annual National Conference, April 7-10, 2005, at Chicago IL.

Willett, Thomas D. 1988. Political Business Cycles: The Political Economy of Money, Inflation, and Unemployment. Durham NC: Duke University Press.

Willett, Thomas D., Ekniti Nitithanprapas, Isriya Nitithanprapas, and Sunil Rongala. 2005. The Asian Crises Reexamined. Asian Economic Papers 3 (3):32-87. 